\title{
Status of fatigue and sleep quality in clinical medical students
}

\author{
Tıp fakültesi klinik dönem öğrencilerinde yorgunluk ve uyku kalitesinin durumu
}

Kübra UYAR, Rana GÜNDOĞAN, Özge Berfu GÜRBÜZ, Nilgün ÖZÇAKAR

\begin{abstract}
Objective: To determine the relationship between fatigue and sleep quality in medical students.

Materials and Methods: We applied a sociodemographic characteristics questionnaire, Pittsburgh Sleep Quality Index (PSQI) and Piper Fatigue Scale (PFS) to $4^{\text {th }}, 5^{\text {th }}$ and $6^{\text {th }}$ year medical students.

Results: Thirty seven percent $(\mathrm{n}=290)$ of $4^{\text {th }}, 5^{\text {th }}$ and $6^{\text {th }}$ year medical students were included in the study. Mean age was $23.47 \pm 1.33$ years, $53.8 \%$ were male. Alcohol use was determined at a level of $40.3 \%(n=117)$, nutrition-drug usage at $40.7 \%(n=118)$, and smoking at $19 \%(\mathrm{n}=55)$. Additionally, $86.2 \%$ of the participants $(\mathrm{n}=250)$ preferred to sleep in the dark, 37.9\% $(\mathrm{n}=110)$ thought that drinks they used before going to bed partially affected their sleep quality. PSQI score was 10.56 \pm 2.54 (min:5-max:19), 98.6\% of the participants had poor sleep quality. There was no significant relationship between the students' academic years and sleep quality. PFS was $2.85 \pm 0.83(\min : 1-\max : 5)$, and $79 \%(n=229)$ had mild fatigue. A statistically significant relationship was determined between PSQI and PFS scores $(\mathrm{p}<0.05)$.
\end{abstract}

Conclusion: Although a large proportion of participants had bad sleep quality, level of fatigue was mild. We determined a significant relationship between levels of fatigue and sleep quality. Arrangements should be made to improve poor sleep quality which affects students' quality of life. Fatigue levels that affect sleep quality should also be reduced.

Keywords: Fatigue, Sleep, Clinical training
ÖZ

Amaç: Tıp fakültesi klinik dönem öğrencilerinde görülen yorgunluk ve uyku kalitesi arasındaki ilişkiyi belirlemektir.

Gereç ve Yöntem: Kesitsel tipteki araştırmamızda üniversitemiz tıp fakültesi 4., 5., ve 6. sınıf öğrencilerine sosyodemografik özellikler anketi, uyku kalitesini değerlendirmeye yönelik Pittsburg Uyku Kalite İndeksi (PUKİ), yorgunluk derecesini belirlemede Piper Yorgunluk Ölçeği (PYÖ) uygulanmıştır.

Bulgular: Dönem 4,5 ve 6. sinıf tıp öğrencilerinin \%37'si $(n=290)$ çalışmaya dahil edilmiştir. Katılımcıların yaş ortalaması $23,47 \pm 1,33$ olup $\% 53,8$ 'i erkekti. Sigara kullanımı \%19 ( $\mathrm{n}=55)$, alkol kullanımı \%40,3 (n=117), uyanık kalmak için ilaç-besin takviye kullanımı \%40,7 (n=118) bulundu. Katılımcıların $\% 86,2$ 'si(n=250) karanlıkta uyumay1 tercih ederken \%37,9'u $(\mathrm{n}=110)$ yatmadan önce tüketilen içeceklerin uyku kalitesini kısmen etkilediğini düşünüyordu. Çalışmamızda toplam PUKİ ortalaması 10,56 $\pm 2,54$ (min:5-maks:19) bulundu. Tüm katılımcılar içerisinde uyku kalitesi kötü olanlar \%98,6 idi. Öğrencilerin bulunduğu sınıflar arasında uyku kalitesi yönünden istatistiksel olarak anlamlı fark yoktur $(\mathrm{p}>0,05)$. Araştırmamızda PYÖ puan ortalamas1 2,85 $\pm 0,83$ (min:1-maks:5) olup kat1lımcıların \%79'unda $(n=229)$ hafif düzeyde yorgunluk bulunmuştur. Katılımcıların yorgunluk ölçeği puanı ortalamalarıyla, PUKİ puanı arasında istatistiksel olarak anlamlı fark bulunmuştur $(\mathrm{p}<0,05)$.

Sonuç: Katılımcıların büyük bir oranı kötü uyku kalitesine sahip olmakla birlikte yorgunluk seviyeleri hafif düzeyde bulunmuştur. Çalışmamızda yorgunluk düzeyi ve uyku kalitesi arasındaki ilişki anlamlıdır. Öğrencilerin yaşam kalitesini etkileyen kötü uyku kalitesini düzeltmeye yönelik düzenlemeler yapılmalı, uyku kalitesine yüksek oranda katkısı bulunan yorgunluk düzeyleri azaltılmaya çalışılmalıdır.

Anahtar kelimeler: Yorgunluk, Uyku, Klinik eğitim dönemi

\section{Introduction}

Sleep is an instinctive, reversible physiological process. Maslow describes sleep as a basic physiological requirement for survival. Our improved ability to examine brain activities 
in recent years has clearly shown that sleep is not simply a passive state of rest when metabolism slows down, but a very complex and organized physiological state affected by several internal and external factors [1-3].

Sleep is essential for a healthy life. It is essential from birth for growth, development, learning, resting and good health. More than half of the adult population sleeps 7-8 hours a night [4]. The quality of sleep, an indispensible part of life, is as important as its duration for rest and a healthy life. There has been considerable focus on sleep quality in clinical practice and research into sleep, but the concept is difficult to define and measure objectively [5]. Complaints about poor quality of sleep are important as potentially indicating several medical diseases. Studies have shown that $15-35 \%$ of adults have disorders concerning sleep quality, such as difficulty falling or remaining asleep [6].

Various factors affect sleep quality. It is affected by environmental factors such as life style, work and social life, economic status, general health and stress. One of the most important factors is fatigue. Fatigued individuals experience problems with sleep onset latency and duration of restful sleep. Fatigue is a state that affects daily life and that can be experienced by anyone at any time. Action should be taken to control the the factors causing fatigue as it will affect the individual's day-to-day activities and quality of life [7]. It may be present alone with no disease components, or may be observed as the basis of accompanying various conditions, from cancer to infectious diseases and from metabolic diseases to psychiatric disorders $[8,9]$.

Fatigue is a widely seen condition. It can appear in healthy individuals, not only those with acute or chronic disease. Fatigue is more common in women than in men, but can affect all age, sex, racial and socioeconomic groups $[10,11]$. University students comprise one group of people who experience severe problems throughout their educational lives due to fatigue and lack of sleep. Fatigue levels in university students have been reported to be equivalent to those in heavy manual laborers [12]. Medical students, who comprise a large percentage of all university students, experience some of the most severe fatigue and sleep problems [13]. Due to the intensive theoretical and practical nature of medical training, the amount of time spent sleeping decreases, and stress and tension are known to reduce sleep quality [14-16].

Medical education is intensive and tiring, particularly in the years of clinical training, so medical students inevitably sacrifice sleep [17]. Attention deficit and physical fatigue may occur in individuals who are unable to sleep enough. This may have an adverse impact on their own health and that of those around them $[15,18]$. Regular sleep is also affected by age, gender, living conditions, exercise and workload [19].

Medical students study on an intensive basis for many years before qualifying as physicians. It is therefore important to know whether they have a sleep problem, the extent of the problem, and also whether their sleep disturbance has any effect on academic performance or quality of life.

The Accreditation Council for Graduate Medical Education (ACGME) attempted to address the problem of fatigue in residents by issuing work limitation standards in 2003 [20].

We think that good quality sleep and adequate amount of sleep are important as sleep disorders can cause fatique and result in a poor cognitive performance, affect lifestyles and interpersonal relationships.

The purpose of this study was therefore to determine the relation between sleep quality and fatigue among clinical medical students.

\section{Materials and Methods}

Ethical approval for this cross-sectional study was granted by the Dokuz Eylül University Non-Interventional Research Ethical Committee in October 2014. Ninety-nine medical students in the $4^{\text {th }}$ year, 91 in the $5^{\text {th }}$ year and 100 in the $6^{\text {th }}$ year at the time when the study was performed were included in the study. These represented $37 \%$ of existing $4^{\text {th }}, 5^{\text {th }}$ and $6^{\text {th }}$ year medical students. Exclusion criteria were conditions known to affect sleep quality, such as depression, anxiety, sleep apnea syndrome, and restless leg syndrome. Participants were administered a demographic characteristics questionnaire, the Pittsburgh Sleep Quality Index (PSQI) and the Piper Fatigue Scale (PFS) to determine fatigue. The PSQI was developed by Buysse et al. and validity and reliability studies for Turkey were performed by P Ağargün et al. Nineteen of the 24 questions in the PSQI are self-reported, the remaining five being answered by a partner or room-mate. Only those questions answered by the respondent are used to evaluate sleep quality. Questions answered by a partner/room-mate (loud snoring, long pauses between breaths, disorientation, legs twitching, other restlessness) are not included in the evaluation and are disregarded during scoring $[5,6]$.

The PFS was developed by Piper et al. The validity and reliability of the Turkish-language version was analyzed 
by Can et al. The PFS has a 5-point Likert-type structure and consists of 22 items. The scale assesses four subjective dimensions of fatigue. Behavioral, affect, sensory and cognition subdimensions are evaluated [21,22].

Statistical analysis was performed using Statistical Package for Social Sciences (SPSS) 15 software. The chi square test was used to compare proportions at analysis between dependent and independent variables, while the Studens' $t$ test was used to compare mean values. Statistical significance was set at $\mathrm{p}<0.05$.

\section{Results}

Mean age of the participants $(\mathrm{n}=290)$ was $23.4 \pm 1.3$ years, and $53.8 \%(\mathrm{n}=156)$ were males. In terms of classes, $34.5 \%$ of students were in the $6^{\text {th }}$ year, $34.1 \%$ in the $4^{\text {th }}(n=99)$ and $31.4 \%(n=91)$ in the $5^{\text {th }}$ year. Fifty percent $(n=145)$ had an income level of 500-999 Turkish lira (TL), 86.2\% $(\mathrm{n}=250)$ were living at home and $76.6 \%$ were living with $2-4$ other students. Nineteen percent $(\mathrm{n}=55)$ were smokers and $40.3 \%(\mathrm{n}=117)$ used alcohol. The use of nutritional drugs in order to stay awake was $40.7 \%(\mathrm{n}=118)$ and the shifts were not worked by the $60.7 \%(n=176)$ of the participants. Two hundred and fifty (86.2\%) medical students preferred to sleep in the dark, and the majority of participants were affected by noise during sleep. Two hundred and tweny eight $(85.5 \%)$ participants were affected by light during sleep, while $76.2 \%(n=221)$ were affected by environmental temperature. Additionally, $37.9 \%(n=110)$ of the students reported that the consumption of drinks containing caffeine before going to sleep affected sleep quality to some degree, and $44.5 \%(n=129)$ of participants assessed their daily consumption of caffeine containing drinks as moderate (Table I). No statistically significant association was determined between sleep quality and gender $(\mathrm{p}=0.87)$, smoking ( $\mathrm{p}=0.33)$, alcohol use $(\mathrm{p}=0.15)$, number of shifts worked $(p=0.58)$, level of light in the sleeping area $(p=0.72)$, quantity of caffeine containing drinks consumed before sleeping ( $\mathrm{p}=0.73$ ), daily consumption of caffeine containing drinks $(\mathrm{p}=0.67)$, or nutritional drug use $(\mathrm{p}=0.09)$. Mild fatigue was present in $79 \%(\mathrm{n}=229)$ of the participants based on PFS scores, while $98.6 \%$ had poor sleep quality according to their PSQI scores.

Mean total PSQI score was 10.5 \pm 2.5 (min:5-max:19), and mean PFI score was 2.8 \pm 0.8 (min:1-max:5). Mean scores for PSQI subscales and PFI subscales are shown in Table II. A statistically significant association was determined between participants' mean fatigue scale scores and PSQI scores. Sleep quality was poor in students with high fatigue levels $(\mathrm{p}<0.001)$.

Table I. Socio-demographic characteristics and factors affecting the quality of sleep

\begin{tabular}{|c|c|c|c|c|}
\hline & & $\mathrm{n}$ & $\%$ & Mean + SD \\
\hline Age & & & & $23.4 \pm 1.3$ \\
\hline \multirow[t]{2}{*}{ Gender } & Female & 134 & 46.2 & \\
\hline & Male & 156 & 53.8 & \\
\hline \multirow[t]{3}{*}{ Class } & $4^{\text {th }}$ & 99 & 34.1 & \\
\hline & $5^{\text {th }}$ & 91 & 31.4 & \\
\hline & $6^{\text {th }}$ & 100 & 34.5 & \\
\hline \multirow[t]{3}{*}{ Income } & $250-499 \mathrm{TL}$ & 46 & 15.9 & \\
\hline & $500-999 \mathrm{TL}$ & 145 & 50 & \\
\hline & $\begin{array}{l}1000 \mathrm{TL} \\
\text { and over }\end{array}$ & 99 & 34.1 & \\
\hline \multirow[t]{2}{*}{ Residence } & Dorm & 40 & 13.8 & \\
\hline & Home & 250 & 86.2 & \\
\hline \multirow{3}{*}{$\begin{array}{l}\text { Number of people } \\
\text { in household }\end{array}$} & Living alone & 55 & 19 & \\
\hline & $2-4$ & 222 & 76.6 & \\
\hline & 5 or more & 13 & 4.5 & \\
\hline \multirow[t]{2}{*}{ Smoking } & Yes & 55 & 19 & \\
\hline & No & 235 & 81 & \\
\hline \multirow[t]{2}{*}{ Alcohol use } & Yes & 117 & 40.3 & \\
\hline & No & 173 & 59.7 & \\
\hline \multirow{2}{*}{$\begin{array}{l}\text { Medication / } \\
\text { supplement use }\end{array}$} & Yes & 118 & 40.7 & \\
\hline & No & 172 & 59.3 & \\
\hline \multirow{4}{*}{$\begin{array}{l}\text { Number of shifts } \\
\text { per month }\end{array}$} & None & 176 & 60.7 & \\
\hline & $1-4$ & 33 & 11.4 & \\
\hline & $5-8$ & 43 & 14.8 & \\
\hline & 9 and over & 38 & 13.1 & \\
\hline \multirow{3}{*}{$\begin{array}{l}\text { Ambient light } \\
\text { level in sleep } \\
\text { environment }\end{array}$} & Light & 12 & 4.1 & \\
\hline & Half-light & 28 & 9.7 & \\
\hline & Dark & 250 & 86.2 & \\
\hline \multirow{2}{*}{$\begin{array}{l}\text { Affected by noise } \\
\text { during sleep }\end{array}$} & Yes & 252 & 86.9 & \\
\hline & No & 38 & 13.1 & \\
\hline \multirow{2}{*}{$\begin{array}{l}\text { Affected by light } \\
\text { during sleep }\end{array}$} & Yes & 248 & 85.5 & \\
\hline & No & 42 & 14.5 & \\
\hline \multirow{2}{*}{$\begin{array}{l}\text { Affected } \\
\text { by ambient } \\
\text { temperature during } \\
\text { sleep }\end{array}$} & Yes & 221 & 76.2 & \\
\hline & No & 69 & 23.8 & \\
\hline \multirow{3}{*}{$\begin{array}{l}\text { Caffeinated } \\
\text { beverages affect } \\
\text { the quality of sleep } \\
\text { before going to } \\
\text { sleep }\end{array}$} & Yes & 93 & 32.1 & \\
\hline & Partially & 110 & 37.9 & \\
\hline & No & 87 & 30 & \\
\hline \multirow{4}{*}{$\begin{array}{l}\text { Daily consumption } \\
\text { of caffeinated } \\
\text { beverages }\end{array}$} & None & 9 & 3.1 & \\
\hline & Low & 63 & 21.7 & \\
\hline & Moderate & 129 & 44.5 & \\
\hline & High & 89 & 34.7 & \\
\hline
\end{tabular}

n: number of participants SD: Standard Deviation 
Table II. Pittsburgh Sleep Quality Index and Piper Fatigue Scale Scores

\begin{tabular}{|c|c|c|c|c|c|}
\hline Scales & Subscales & & Minimum & Maximum & Mean + SD \\
\hline \multirow[t]{8}{*}{ Pittsburgh Sleep Quality Index } & Sleep duration & & 0 & 3 & $0.7 \pm 0.9$ \\
\hline & Sleep disturbances & & 1 & 3 & $2.1 \pm 0.5$ \\
\hline & Sleep latency & & 1 & 3 & $1.5 \pm 0.6$ \\
\hline & Daytime dysfunction & & 1 & 3 & $2.1 \pm 0.8$ \\
\hline & Habitual sleep efficiency & & 0 & 3 & $0.5 \pm 1.0$ \\
\hline & Subjective sleep quality & & 1 & 3 & $2.2 \pm 0.5$ \\
\hline & Use of sleeping medication & & 1 & 4 & $1.1 \pm 0.5$ \\
\hline & & Total score & 5 & 19 & $10.5 \pm 2.5$ \\
\hline \multirow[t]{5}{*}{ Piper Fatigue Scale } & Behavioral/severity & & 1 & 5 & $2.6 \pm 0.9$ \\
\hline & Affective meaning & & 1 & 5 & $3 \pm 0.9$ \\
\hline & Sensory & & 1 & 5 & $2.8 \pm 0.9$ \\
\hline & Cognitive/mood & & 1 & 5 & $2.8 \pm 0.9$ \\
\hline & & Total score & 1 & 5 & $2.8 \pm 0.8$ \\
\hline
\end{tabular}

SD: Standard Deviation

\section{Discussion}

Mild fatigue was determined in this study involving $4^{\text {th }}$ $6^{\text {th }}$ year medical students, and a significant relation was determined between sleep quality scale and fatigue scale scores.

Several factors can affect sleep quality. Gender is one of the factors, but no significant relationship was observed between gender and sleep quality in this study. The findings of studies investigating the interaction between gender and sleep are inconsistent. While some have reported that women experience more sleep problems than men (Keshavarz et al., Orzech et al.), Liu et al., have reported poorer sleep quality in males than in females [23-25].

Smoking and alcohol are significant factors affecting the sleep/wake cycle. Cigarettes have a stimulating effect due to the nicotine they contain, while alcohol affects the sleepwake cycle and the length of time spent sleeping [26].

Studies in the literature have suggested that smoking and alcohol use have an adverse effect on sleep quality. VailSmith et al., reported a correlation between risky behavior such as smoking and alcohol use and mean sleep quality scores [27]. Sar1 et al., in their study about students living in university campus accommodation, reported a higher incidence of poor sleep quality among a group using alcohol compared to a group that did not use alcohol [28]. No significant association was determined in our study between smoking or alcohol use and sleep quality. This may be due to the amount of daily cigarettes smoked or alcohol used by students not being known and to different levels of use among participants.
One of the underlying causes of fatigue, regarded as one of the basic factors affecting sleep quality, is an irregular and shift-based work pattern. The literature reports that a 1.5 -hour decrease in nocturnal sleep reduces wakefulness the following day by $23 \%$ [29]. Studies involving nurses have reported that working night shifts has an adverse effect on sleep quality and that shift fatigue persists the following day [30]. No statistically significant association was observed between shift work and sleep quality in the present study. Mayda et al., reported similar results in a study of the prevalence of sleep disturbance among $4^{\text {th }}, 5^{\text {th }}$ and $6^{\text {th }}$ year medical students [31]. The absence of a significant association between work shift and sleep quality in our study may be attributed to a large proportion of students at the time of the study being in departments where shifts were not worked (60.7\%) or to their living at home $(86.2 \%)$.

No significant relations were also observed between sleep quality and the level of environmental light or the amount of caffeine containing drinks consumed before going to bed and during the day. The level of environmental light affects sleep onset latency and the nature of sleep. In Sarı et al.'s study on students living in a university campus accommodation, students experiencing difficulties in falling asleep reported factors such as noise and light levels in their rooms as the most common cause of this problem [28]. The fact that the great majority of participants in our study preferred to sleep in the dark may have been responsible for the absence of a statistically significant difference. Although studies reporting that the consumption of caffeine containing drinks adversely affects sleep quality and causes interruptions in sleep are in the majority, there are also 
publications reporting the opposite, that consumption of tea and coffee does not affect quality of sleep [32,33]. In our study, too, no significant correlation was observed between consuming caffeine containing drinks and sleep quality.

While fatigue was mild in the great majority of students in this study, surprisingly the percentage of participants with poor sleep quality was high $(98.6 \%)$. This may be due to students becoming used to the intensive and tiring tempo of medical education, particularly in the years of clinical training, means that students sacrifice sleep. The mean PSQI score in this study was $10.5 \pm 2.5$ (min:5max:19) and the mean PFI score was $2.8 \pm 0.8$. Similarly, in a study investigating fatigue and sleep quality in students at various departments in the fields of technical sciences, arts and sciences, social sciences and health, Saygilı et al. reported mean PSQI and PFI scores of 6.9+2.4 and 4.3+2.2, respectively [34]. Mayda et al. investigated sleep disorder in $4^{\text {th }}, 5^{\text {th }}$ and $6^{\text {th }}$ year medical students and reported a mean PSQI score of $5.2 \pm 2.7$ [31]. In their study investigating physical activity levels, sleep quality and depression levels among university students, Işı et al. reported a mean PSQI score of $8.5 \pm 2.9$ [35]. The higher mean PSQI score in our study may be due to the higher number of students living at home when compared to other researches. As with all university students working at an intensive and tiring tempo, poor sleep quality was also determined in medical faculty students. A good quality sleep is known to make an important contribution to individuals' physical, psychological and social development. Education-instruction programs therefore need to be arranged considering medical students' fatigue levels and heavy workload. Sleeping and waking hours being regular and high quality will enable students to feel fit and healthy in their daily lives and will increase their academic success, thus contributing to their emerging as good physicians in the future.

\section{References}

1. Özgen F. Uyku ve uyku bozuklukları. Psikiyatri Dünyası 2001; 5:41-8.

2. Birol L. Hemşirelik Süreci. 5. Bask1, İzmir: Etki Matbaacılık Yayınc1l1k Ltd, 2002.

3. Akersted T, Billiard M, Bonnet M, et al. Awakening from sleep. Sleep Med Rev 2002;6:267-86. doi:10.1053/ smrv.2001.0202

4. Sneerson JM. Handbook of sleep medicine. Oxford:Blackwell science Ltd, 2000:1-15.

5. Buysse DJ, Reynolds CF, Monk TH, Berman SR, Kupfer DJ. The Pittsburgh Sleep Quality Index: A new instrument for psychiatric practice and research. Psychiatr Res 1989;28:193213. doi:10.1016/0165-1781(89)90047-4
6. Ağargün MY, Kara H, Anlar Ö. Pittsburgh Uyku Kalitesi İndeksi'nin geçerlik ve güvenirliği. Turk Psikiyatr Derg 1996; 7:107-15.

7. Yurtsever S. Kronik hastalıklarda yorgunluk ve hemşirelik bakımı. C. Ü. Hemşirelik Yüksekokulu Dergisi 2000;4:1620.

8. Bates DW, Schmitt W, Buchwald D, et al. Prevalance of fatigue and chronic fatigue syndrome in a primary care practice. Arch Int Med 1993; 153: 2759-65. doi:10.1001/ archinte.1993.00410240067007

9. Yeşilbalkan ÖU. Kemoterapi uygulanan hastalarda eğitimin yorgunluk düzeyine ve yaşam kalitesine olan etkisinin incelenmesi. Doktora Tezi, Ege Üniversitesi Sağlık Bilimleri Enstitüsü, İzmir 2005.

10. Kroenke K, Wood DR, Mangelsdorff AD, Meier NJ, Powell JB. Chronic fatigue in primary care. Prevalance, patient characteristics, and outcome. JAMA 1988; 260: 929-34. doi:10.1001/jama.1988.03410070057028

11. Sharar E, Lederer J. Asthenic symptoms in a rural family practice. Epidemiologic characteristics and a proposed classification. J Fam Pract 1991; 32: 14-23.

12. Oginska H, Pokorski J. Fatigue and mood correlates of sleep length in three age-social groups: School children, students, and employees. Chronobiol Int 2006;23:1317-28. doi: 10.1080/07420520601089349

13. Veldi M, Aluoja A, Vasar V. Sleep quality and more common sleep-related problems in medical students. Sleep Med 2005; 6:269-75. doi:10.1016/j.sleep.2004.12.003

14. Azad MC, Fraser K, Rumana N, et al. Sleep disturbances among medical students: a global perspective. J Clin Sleep Med 2015;11:69-74. doi: 10.5664/jcsm.4370

15. Altaf M, Altaf F, Iftikhar A, Goha S Yusra. Workload and health problems in medical students. Int J Endorsing Health Sci Res 2013;1:69-72.

16. Abdulghani HM, Alrowais NA, Bin-Saad NS, AlSubaie NM, Haji AM, Alhaqwi AI. Sleep disorder among medical students: relationship to their academic performance. Med Teach 2012;34 Suppl 1:S37-41. doi: 10.3109/0142159X.2012.656749.

17. Alsaggaf MA, Wali SO, Merdad RA, Merdad LA. Sleep quantity, quality, and insomnia symptoms of medical students during clinical years. Relationship with stress and academic performance. Saudi Med J 2016;37:173-82. doi: 10.15537/ smj.2016.2.14288.

18. Chinawa JM1, Chukwu BF, Obu HA. Sleep practices among medical students in Pediatrics Department of University of Nigeria Teaching Hospital, Ituku/Ozalla, Enugu, Nigeria. Niger J Clin Pract 2014;17:232-6. doi: 10.4103/11193077.127565 .

19. Giri P1, Baviskar M, Phalke D. Study of sleep habits and sleep problems among medical students of pravara institute of medical sciences loni, Western Maharashtra, India. Ann Med Health Sci Res 2013;3:51-4. doi: 10.4103/21419248.109488.

20. http://www.acgme.org/portals/0/pfassets/publicationspapers/ dh_dutyhoursummary2003-04.pdf Assessed on 10.06.2016

21. Piper BF, Dibble SL, Dodd MJ, Weiss MC, Slaughter RE, Paul SM. The revised piper fatigue scale; psychometric 
evaluation women with breast cancer. Oncol Nurs Forum 1998; 25: 677-84.

22. Can G. Meme kanserli hastalarda yorgunluğun ve bakım gereksinimlerinin değerlendirilmesi. yayınlanmamış doktora tezi, Sağlık Bilimleri Enstitüsü, İstanbul, 2001.

23. Akhlaghi KAA, Ghalebandi MF. Sleep quality and its correlation with general health in preuniversity students of Karaj. Iranian J Psychiatr Behavioral Sci 2009;3: 44-9.

24. Orzech KM, Salafsky DB, Hamilton LA. The state of sleep among college students at a large public university. J Am Coll Health 2011; 59: 612-9. doi: 10.1080/07448481.2010.520051

25. Liu X, Zhao Z, Jia C, Buysse DJ. Sleep patterns and problems among Chinese adolescents. Pediatrics 2008;121:1165-73. doi: 10.1542/peds.2007-1464

26. Aysan E, Karaköse S, Zaybak A. ve ark. Üniversite öğrencilerinde uyku kalitesi ve etkileyen faktörler. Dokuz Eylül Üniversitesi Hemşirelik Yüksekokulu Elektronik Dergisi 2014;7, 193-198.

27. Vail-Smith K, Felts WM, Craig C. Relationship between sleep quality and health risk behaviors in undergraduate college students. College Student Journal 2009; 43::924-930.

28. Sarı ÖY, Üner S, Büyükakkuş B. Bostancı EÖ, Çeliksöz AH, Budak M. Bir üniversitenin yurtta kalan öğrencilerinde uyku kalitesi ve etkileyen bazı faktörler. TAF Prev Med Bull
2015;14:93-100. doi: 10.5455/pmb1-1408013434

29. Karagozoglu S, Bingöl N. Sleep quality and job satisfaction of Turkish nurses. Nurs Outlook 2008; 56:298-307. doi: 10.1016/j.outlook.2008.03.009.

30. Zverev YP, Misiri HE. Perceived effects of rotating shift work on nurses sleep quality and duration. Malawi Med J 2009; 21: 19-21.

31. Mayda A, Kasap E, Yildırım C. ve ark. 4-5-6. Sinıf Tıp Fakültesi öğrencilerinde uyku bozukluğu sıklığ1. Düzce Üniversitesi Sağlık Bilimleri Enstitüsü Dergisi 2012; 2: 8-11.

32. Shcao MF, Chou YC, Yeh MY, Tzeng WC. Sleep quality and quality of life in female shift working nurses. J Adv Nurs 2010; 66 :1565-72. doi: 10.1111/j.1365-2648.2010.05300.x

33. Çalıyurt O. Sirkadiyen uyku uyanıklık düzenini etkileyen iş ve çalışma gruplarında uyku kalitesinin değerlendirilmesi. Yayınlanmamış Uzmanlık Tezi, Trakya Üniversitesi Tıp Fakültesi Psikiyatri Anabilim Dalı. Edirne, Türkiye, 1998.

34. Saygılı S, Akıncı AÇ, Arıkan H, Dereli E. Üniversite ögrencilerinde uyku kalitesi ve yorgunluk. Electronic Journal of Vocational Colleges 2011:88-94.

35. Işık Ö, Özarslan A, Bekler F. Üniversite öğrencilerinde fiziksel aktivite uyku kalitesi ve depresyon ilişkisi. Niğde Üniversitesi Beden Eğitimi ve Spor Bilimleri Dergisi 2015; 9: 65-73. 